\title{
GRAPHIUM ANDROCLES BOISDUVAL (LEPIDOPTERA: PAPILIONIDAE): EVALUATION OF BIOLOGICAL ASPECT OF THE PRE-ADULT STADIA AT BANTIMURUNG, SOUTH SULAWESI, INDONESIA
}

\author{
HARLINA $^{1}-$ BASUKRIADI, A. $^{2}-$ ACHMAD, A. $^{3}-$ PEGGIE, D. $^{4}$ \\ ${ }^{1}$ Graduate School of Biology, Faculty of Mathematics and Science, University of Indonesia \\ ${ }^{2}$ Biology Department, Faculty of Mathematics and Science, University of Indonesia. \\ ${ }^{3}$ Faculty of Forestry, Hasanuddin University, Makassar, Indonesia. \\ ${ }^{4}$ Zoology Division (Museum Zoologicum Bogoriense), Research Center for Biology-LIPI, \\ Cibinong, Indonesia \\ *Corresponding author \\ e-mail: harlinagusasi@gmail.com \\ (Received 24 $4^{\text {th }}$ Oct 2016; accepted $7^{\text {th }}$ Mar 2017)
}

\begin{abstract}
G. androcles is one of the endangered butterflies categorized as endemic species in Sulawesi region. This study aimed to determine the biological aspect of the pre-adult stadia of G. androcles through breeding efforts at the laboratory. The study was conducted from July until November 2014. The butterfly eggs were collected from the tourist area, Pattunuang, and were then reared in the laboratory. The larval rearing technique was using covered method placed in captivity. The time needed from eggs to develop to adults varies, ranging from 46-65 days. The time needed for eggs to develop to the larval stage ranges from 5-9 days. Larval stage consists of five instars, and development time is 23-30 days. Each of prepupal and pupal stages needed 2-3 days and 20-25 days, respectively. The percentage of survival rate for egg, larva, prepupa, and pupa to imago stages were $42 \%, 90 \%, 100 \%$, and $70 \%$, respectively. The eggs which failed to hatch were $38 \%$, where $12 \%$ eggs were harmed by Camponotus sp, and $8 \%$ eggs were moldy. Aleoides indiscretus was a parasite that harmed the L4 instar. G. androcles activities in the laboratory and in captivity were behavioral responses as a way to adapt to the environmental conditions.

Keywords: butterflies, Sulawesi, breeding, parasite, behavior
\end{abstract}

\section{Introduction}

Graphium androcles is one of the nation's insect species that has beautiful colors and a beautiful shape of wings (Whitten et al., 2002). Butterfly has an important role in nature as pollinator in the pollination process. It is ecologically helpful in maintaining the ecosystem equilibrium and enriching the biodiversity (Vane-Wright and De Jong, 2003). Graphium androcles is one of the rare butterfly species endemic to Sulawesi, Banggai and Sula (which politically belongs to Maluku province). This species can be found at the Bantimurung-Bulusaraung (TN Babul) and its surrounding area (Durden, 2010). However, its presence is fluctuated and affected by climate (Whitten et al., 2002). One effort to protect the existence of the butterfly from extinction is maintaining their sustainability through captive butterfly breeding.

The survival rate of butterflies in captivity are supported by the information of their biological aspects; including food resources, both for larval and imago stages (Kartsev, 
2014). The butterfly life cycle is started from the egg until becoming an imago and lays its eggs for the first time (Solomon, 1976). Scriber and Slansky (1981) and Courtney (1984) mentioned that shorter life cycles of butterflies indicate the increase in population. The lifespan of butterflies is determined by the quality and quantity of plant, refers to the water and nitrogen content, as their food to support the growth of their larvae. However, other factors also play important parts and affect their lifespan, such as the attack by their natural enemies, including predators, parasitoids, and pathogens.

There are many types of research conducted to determine the biological aspects of butterflies in South Sulawesi, particularly around Babul National Park. However, the evaluation of the biological aspects of $G$. androcles has never been conducted, so it remains uncertain. This study aimed to determine the biological aspects of $G$. androcles through captive breeding efforts in the butterfly breeding laboratory, Bantimurung. The research results are expected to be a reference for the government and local communities in developing the captive butterfly breeding, especially G. androcles, and as a reference for a further study on $G$. androcles.

\section{Materials and Methods}

This study used a descriptive observation method with case study technique of the life cycle of pre-adult $G$. androcles.

\section{Time and location}

The study was conducted from July to November 2014. The observation of morphology and life cycle of $G$. androcles was conducted in the breeding laboratory Bantimurung, located near the entrance to the tourism area of Bantimurung, Maros, South Sulawesi, Indonesia. Eggs were collected at Pattunuang tourism area, Maros, South Sulawesi province.

\section{Preparation of larva rearing cage in the captive breeding}

The larva rearing cage were placed in a room for captive breeding which sized approximately $12 \mathrm{~m}$ height and $7000 \mathrm{~m}^{2}$ width. The cage framework was made of wood and shading net with the size of $3 \times 3 \times 3 \mathrm{~m}$. Furthermore, the cutting plants, Uvaria rufa, were transferred to the cage and the cage were cleaned. Inside the cage, organdy fabric was used to cover the larva during its development.

\section{Preparation of pupa rearing cage in the laboratory}

The laboratory was cleaned before conducting the research. Pupa rearing cage was sized $1 \times 0.45 \times 2 \mathrm{~m}$ made of steel frame and shading net with a door to place the pupa and release imago at the time of eclosion. The ant chalk was used in order to avoid ant by drawing a line around the cage. Tongs and rope were used for hanging the pupae.

\section{Egg collection}

Eggs were collected from the leaves of host plants Uvaria rufa and reared in the laboratory. G. androcles eggs were collected by climbing the host tree of $U$. rufa, then the leafstalks where the eggs attached were cut. Aferwards, the eggs were reared in the laboratory. 


\section{Observations on the morphology and life cycle of pre-adult stadia of G. androcles}

Leaves with $G$. androcles eggs were put in a glass bottle, $10 \mathrm{~cm}$ height, filled with water. Tip of the leafstalk was wrapped with a wet paper towel and planted into the bottle. The glass bottle was placed into the $40 \mathrm{~cm}$ gauze-covered jar to maintain the temperature and humidity and to protect from predators. During the rearing process, the paper towel was controlled to be always in wet condition. Eggs were labeled based on the days the eggs were laid. The supporting data was recorded, included the place and position of the eggs laid on leaves and the number of eggs hatched into the first instar larva (L1). The temperature and humidity were measured every day and the egg condition was checked for any harmful parasitoids and other predators. Data were recorded in an observation sheet.

The newly hatched instar larvae were transported into larva rearing cage. To avoid predators, the leaves were wrapped with net fabric (Figure 1) and marked with plastic straps which were attached by larvae. Each released larva was marked with permanent ink to avoid double counting. Loops were used to ensure that the larvae corresponded with their color ID. Larva condition was recorded on the observation sheet.

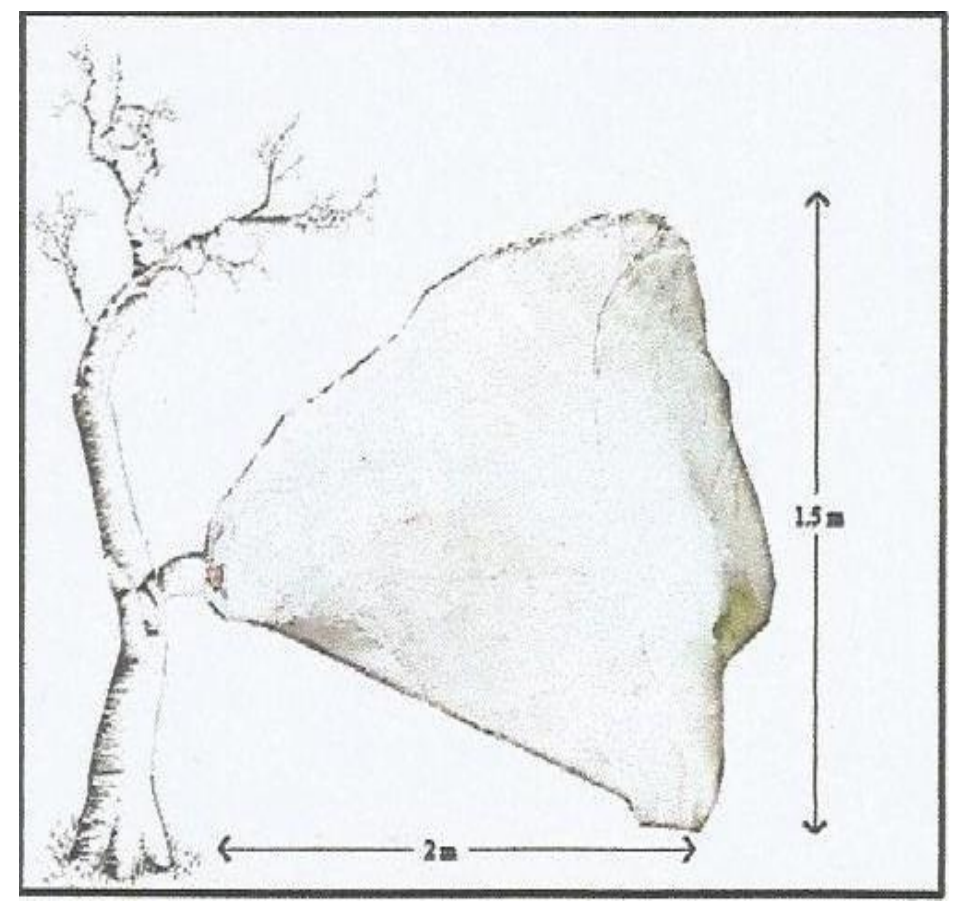

Figure 1. Sketch of larval rearing techniques

The larva entered prepupa stage after completing the last instar. The duration of the prepupa stage was determined from the first time larva attached to the bottle until it became complete pupa. The net fabric was detached after larva became prepupa, then pupa was placed in a plastic jar, the height of $30 \mathrm{~cm}$, covered with gauze and transferred to the pupa rearing cage in the laboratory. The duration of pupa stage was determined from the beginning of pupal completion to adult butterfly. Pupae were observed every day in order to avoid harm and mortality due to predators and parasitoids. The damaged pupae were immediately removed from the cage to prevent transmission to other pupae. The pupation time was counted from the time of pupa formation until it was 
transformed into imago. Imago was released to the captive breeding after the wings have hardened (approximately about 2 to 3 hours after eclosion). Data were recorded in observation sheet.

\section{Observation of natural enemies of G. androcles}

The observation was performed simultaneously with the observation of butterfly life cycle. Data was recorded from the time when eggs were collected until they transformed into imago stage. Additional information about each of egg stage was also recorded, including the hatched eggs or failed to hatch eggs due to parasites, parasitoids, predators, or pathogen.

The attack of natural enemies towards larvae, prepupae, and pupae were also observed. The damaged indicated by a hole caused by parasitoid in each stage was recorded. Died specimen was stored in a collection bottle containing $70 \%$ alcohol and was then identified.

\section{Data analysis}

Data of pre-adult G. androcles were analyzed qualitatively and quantitatively. The duration of each phase was presented in table format and then described chronologically. The identification of natural enemies was conducted at the Laboratory of Zoology, Faculty of Mathematics and Natural Sciences, Hasanuddin University based on Nauman (1991), Huang and Noyes (1994), Goulet and Huber (1993), Bolton (1994). The percentage of hatched eggs, larvae, and pupae were determined based on following (Eq. 1) (Birch, 1948).

$$
\begin{gathered}
\text { Hatched eggs percentage }=\frac{\text { hatched eggs amount }}{\text { gggs total }+ \text { failed hatched } \text { aggs }} \times 100 \% \\
\text { Survived larvae percentage }=\frac{\text { survived larve }}{\text { larvas total }} \times 100 \% \\
\text { Survived pupae percentage }=\frac{\text { survived pupae }}{\text { pupae total }} \times 100 \%
\end{gathered}
$$

\section{Results}

\section{Lifespan of pre-adult stadia of $G$. androcles in the captive breeding}

The lifespan of pre-adult $G$. androcles that attached on the $U$. rufa plants varied (Table 1).

Table 1. The lifespan of pre-adult G. androcles in the laboratory and captive breeding. $S D=$ Standard Deviation

\begin{tabular}{l|l|l|l}
\hline Stadia & Amount $(\mathbf{s})$ & Duration (days) & Average \pm SD (days) \\
\hline Egg & 26 & $5-9$ & $7.19 \pm 1.60$ \\
\hline Larvae & 11 & $20-30$ & $26.83 \pm 0.82$ \\
\hline L1 & 11 & $4-8$ & $5.45 \pm 1.29$ \\
\hline L2 & 11 & $4-5$ & $4.19 \pm 0.50$ \\
\hline L3 & 11 & $4-6$ & $4.64 \pm 0.77$ \\
\hline
\end{tabular}




\begin{tabular}{l|l|l|l}
\hline L4 & 10 & $4-7$ & $5.37 \pm 0.81$ \\
\hline L5 & 10 & $4-7$ & $4.64 \pm 0.75$ \\
\hline Prepupae & 10 & $2-3$ & $2.56 \pm 0.52$ \\
\hline Pupae & 10 & $20-23$ & $21.6 \pm 1.07$ \\
\hline Total duration & & $46-65$ & $60.46 \pm 0.91$ \\
\hline
\end{tabular}

\section{Morphology of preadult G. androcles}

The morphology of pre-adult $G$. androcles that attached on the $U$. rufa plants varied (Table 2, Figure 2).

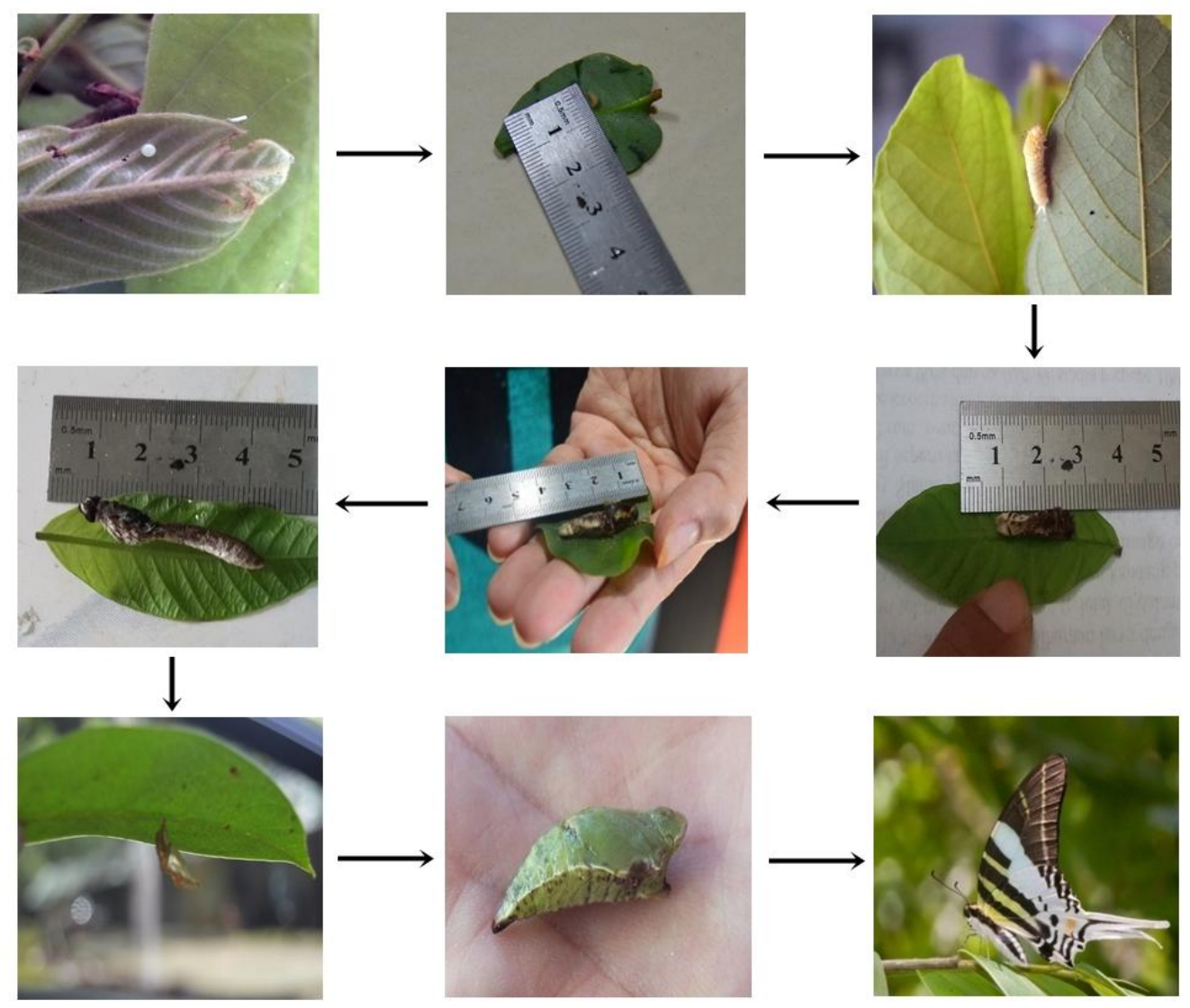

Figure 2. The life cycle of butterfly G. androcles

Table 2. The size of each stadia of preadult $G$. androcles

\begin{tabular}{l|l|l}
\hline Size/Instar & Size $(\mathbf{m m})$ & Average \pm SD $(\mathbf{m m})$ \\
\hline Egg & & \\
Egg diameter & $1,25-0,30$ & $1,27 \pm 0,02$ \\
\hline instar larvae 1 & & \\
Body length & $0.5-0,10$ & $0,69 \pm 0,63$ \\
Head-shell diameter & 0,10 & $0,10 \pm 0,00$ \\
\hline
\end{tabular}




\begin{tabular}{l|l|l}
\hline instar larvae 2 & & \\
Body length & $0,8-15,00$ & $11,65 \pm 0,75$ \\
Head-shell diameter & 0,35 & $0,35 \pm 0,00$ \\
\hline instar larvae 3 & $18,50-20,30$ & $19,50 \pm 1,96$ \\
Body length & $2,00-2,30$ & $2,1 \pm 0,14$ \\
Head-shell diameter & & \\
\hline instar larvae 4 & $25,05-30,00$ & $28,68 \pm 2,34$ \\
Body length & $3,40-3,50$ & $3,45 \pm 0,14$ \\
Head-shell diameter & & \\
\hline instar larvae 5 & $32,00-45,00$ & $37,53 \pm 3,14$ \\
Body length & $5,30-6,35$ & $5,68 \pm 0,44$ \\
Head-shell diameter & $44,00-45,00$ & $46,00 \pm 0,66$ \\
\hline Prepupae & $45,00-50,00$ & $45,77 \pm 1,13$ \\
\hline Pupae &
\end{tabular}

\section{Natural enemies of G. androcles in the laboratory and captive breeding}

The percentage of hatching failure caused by ants before being collected, fungi, and other factors were $12 \%, 8 \%$, and $38 \%$, respectively. Other factors were expected to be due to a lack of fertility. Morphology of damaged eggs can be seen in (Figure 3).

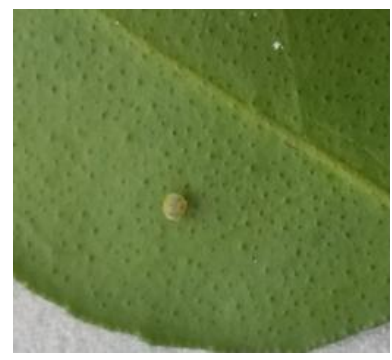

(A)

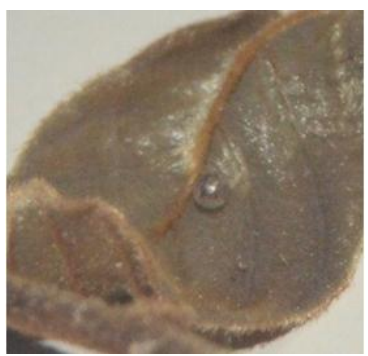

(B)

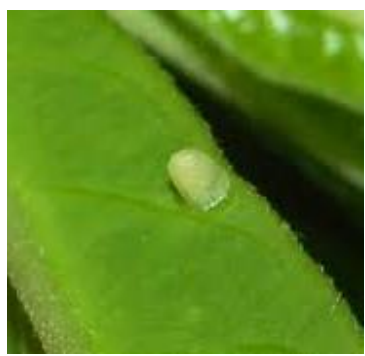

(C)

Figure 3. Empty egg (A), blackened and translucent egg (B), and moldy egg $(C)$

White and empty eggs indicated a damage caused by ants from Camponotus sp. (Figure 4) which belongs to Hymenoptera, Family Formicidae (Goulet and Huber 1993; Bolton 1994). Blackened eggs indicated sterile eggs or infertile eggs. Yellow and white eggs indicated pathogens or fungi that attached on eggshells. Morphology of Camponotus sp. can be seen in (Figure 4).

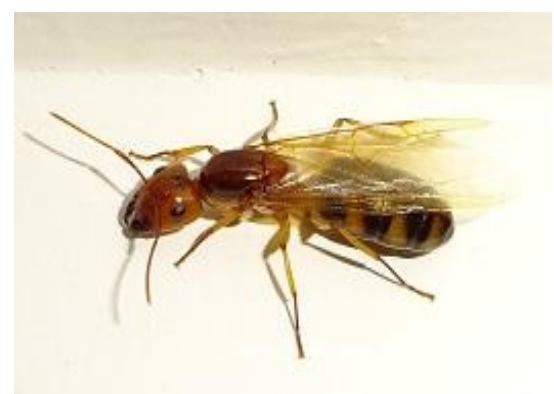

Figure 4. Morphology of Camponotus sp. 
Parasite that attacked the larval stage was identified as Aleiodes indiscretus (Hymenoptera: Braconidae) (Figure 5).

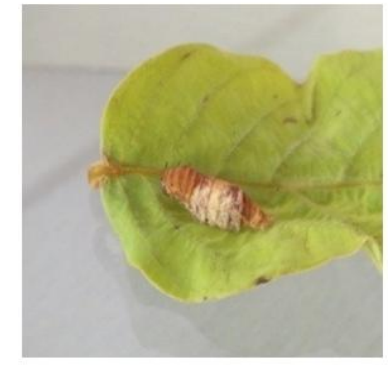

(A)

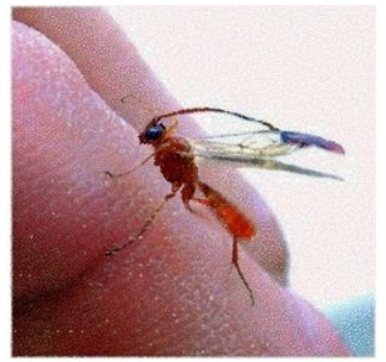

(B)

Figure 5. Larvae were attacked by A. indiscretus (A), and morphology of A. indiscretus (B)

Once entering the prepupal phase, larvae were no longer attacked by their natural enemies and all of them were successful in transforming into pupae. Failure on becoming imago was not caused by their natural enemies, but due to the changes in their initial form from larvae to pupae. In addition, cremaster that was not stuck properly would cause pupae to attach improperly and thus fall. Another factor was being attacked by their pathogens (Figure 6).

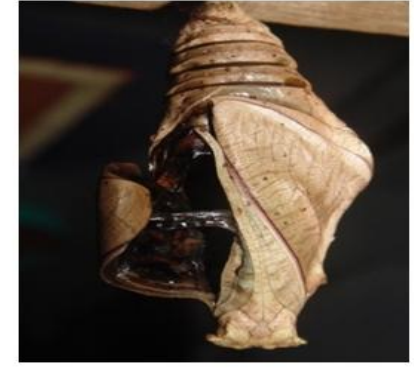

(A)

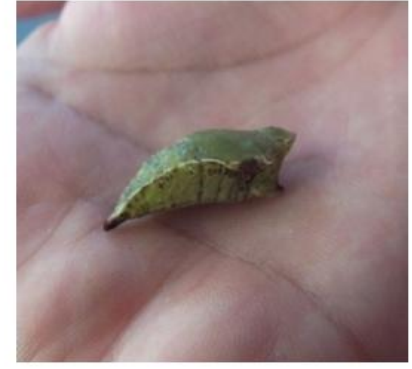

(B)

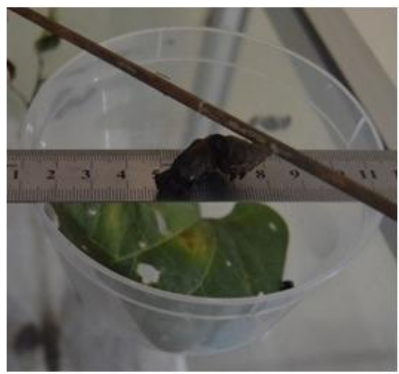

(C)

Figure 6. Not-fully formed pupa (broken) (A), pupa fell due to itstheir cremaster was not attached properly $(B)$, and blackened pupa $(C)$

The highest survival percentage of the egg metamorphosed into imago happened in the prepupal stadia. All of the prepupae were metamorphosed into pupae with a survival percentage $100 \%$. However, the survival percentage of pupae metamorphosed into imago was about $70 \%$, and the rest, 30\%, were failed to metamorph. The highest death rate happened in the eggs stadia (58\%). From $26 \mathrm{eggs,} 42 \%$ of them were hatched into larvae. Previously, the larval stadia consisted of 11 individuals, but 1 individual failed to survive at L4 instar stadium.

\section{Discussion}

The butterfly $G$. androcles requires a different rearing technique than other butterflies that have been reared in the captive breeding of Bantimurung. Egg-hatching failure was caused by Camponotus sp. and happened before being reared in the captive 
breeding. Camponotus sp. has a maroon body color with $0.5 \mathrm{~mm}$ length in average. It has 13 antennal segments, the first segment, called metasoma, sometimes consists of two segments; cubic-shaped pronotum on the lateral view; and feeler organs that are usually angled (Borror et al., 1992). They are classified as pests towards plants, consuming water reserves in plants and some fungi. Therefore, G. androcles eggs were placed in a closed jar as a protection from their natural enemies during research. According to Straatman (1971) and Matsuka (2001), in nature, parasites and predators can cause death to eggs at approximately $80-100 \%$.

Special treatment was given to $G$. androcles eggs due to their sensitiveness to the environmental conditions. Rearing eggs on the freshly-picked $U$. rufa leaves is presumed to help hatching process due to its resemblance to a natural condition. Eggs need 5-9 days to hatch into larvae. Larvae are transferred into larva rearing cage and to avoid natural enemies. The attack of parasite A. indiscritus occurred during the fourth instar larva (L4). This parasite belongs to wasp with $0.5 \mathrm{~mm}$ length. The parasite $A$. indiscretus attacked $G$. androcles larva by injecting poison into larva abdomen and legs. According to Borror et al. (1992), adult female A. indiscretus usually oviposits to the host organism which would become parasitoid and would cause death to its host.

In the wild, the diversity of butterflies may decline because of their natural enemies (Brower and Calvert, 1985). Larval rearing technique by using semi-natural cage are related to the ability of $G$. androcles larvae in consuming host plants, especially during L1 and L2 instar stadia which only consumed shoots or young leaves of $U$. rufa. This butterfly species is easier to be reared in the semi-natural cage because the food is more controllable. The water content in the host plant has a function in the insect metabolism (Behmer, 2006). Tip-Pyang et al. (2011) mentioned that $U$. rufa has leaves that easy to wilt, herb-potential roots, and can be used as an aesthetical plant.

Courtney 1984 in Dahelmi (2008) stated that the quality of the host plant affects the butterfly lifespan. Butterflies depend on its host before finishing their metamorphosis process. Some butterflies have a longer lifespan and normal size, and some have a shorter lifespan and smaller size or flawed. Larvae need water and nitrogen obtained from host plants, which are essential for larval growth. The quality of host plant will affect larval development, particularly their size. The average body growth of L1 - L5 . Based on research conducted by Helmiyetti et al. (2012), the lifespan of Papilionidae butterfly reared on the host plant Citrus hystrix, included Papilio demoleus, P. polytes, P. memnon, are 26-29, 24-27, and 30-32 days, respectively. Therefore, the differences in butterflies lifespan varied and depend on the butterfly species and the host plant species, especially their nutrient contents that affect the growth and the development of butterfly larvae.

The highest survival percentage rate of $G$. androcles occurred during instar L1 - L5 (90\%). Otherwise, the lowest survival percentage rate occurred during imago stage $(11 \%)$. This phase was supposed to be successful since the laboratory maintenance for rearing pupae had been improved. However, a damage by natural enemies usually happened, that ruined pupal formation and caused blackened pupae. The aggression by fungi and virus can be related to the humidity and temperature conditions of the room. Kuroyanagi et al. (2013) mentioned that high humidity and closed air circulation are a proper condition for fungi and virus to grow. The presence of fungi and virus are harmful to the eggs, larvae, and pupae development since they will be blackened and rotted because of fungi and virus. Matsuka (2001) stated that $100 \%$ of pupae will die when attacked by fungi and virus. In this case, the laboratory cleanliness and the 
equipment sterility need to be improved. In order to minimize the harm caused by the natural enemies, eggs are kept inside the gauze-covered jar, larvae are covered with net fabrics, and pupae are placed in an enclosed cage in the laboratory.

\section{Conclusions}

1. The duration for G. androcles eggs, larvae (5 instars), prepupae, and pupae phase were 5-9, 20-30, 2-3, and 20-23 days, respectively. Therefore, total lifespan of the entire phase before transforming into an imago was 46-65 days.

2. The rearing technique for larvae $G$. androcles towards prepupal phase in the rearing cage by using covered method is recommended since the larval survival chance was $90 \%$.

3. The survival percentage of $G$. androcles eggs was $42 \%, 11$ eggs (44\%) were hatched and 10 eggs (32\%) were failed to hatch. The rest of them, 3 eggs (12\%) were attacked by ants, and 2 eggs $(8 \%)$ were harmed by fungal pathogens.

4. Camponotus sp. is predatory ant and A. indiscretus is parasitoid that harmed the fourth instar larvae of $G$. androcles.

Acknowledgements. This study was facilitated by Babul National Park, South Sulawesi, Indonesia. We are highly grateful to KSP Duta Mandiri Community who had b provided financial assistance for this study.

\section{REFERENCES}

[1] Behmer, S.T. (2006): Insect Dietary Needs: Plants as Food for Insect. - Texas A\&M University, USA.

[2] Birch, L.C. (1948): The Intrinsic Rate of Natural Increase of an Insect Population. - In: Hazen, E.W. (ed.) Reading in Population and Community Ecology, Saunders Company, London.

[3] Bolton, B. (1994): Identification Guide to the Ant Genera of the World. - Harvard University Press, USA.

[4] Borror, D.J., Triplehorn, C.A., Johnson, N.F. (1992): Pengenalan Pelajaran Serangga (Terjemahan). - Gadjah Mada University Press, Yogyakarta.

[5] Brower, L.P., Calvert, W.H. (1985): Foraging Dynamics of Bird Predators on Overwintering Monarch Butterflies in Mexico. - Evolution 39: 852-868.

[6] Courtney, S.P. (1984): Habitat Versus Food Plant Selection. - In: Vane-Wright, R.I., Arckery, P.R. (eds.) The Biology of Butterflies, Academic Press, London.

[7] Dahelmi, Salmah, S., Abbas, I., Fitriana, N., Nakano, S., Nakamura, K. (2008): Duration of Immature Stages of Eleven Swallowtail Butterflies (Lepidoptera:Papilionidae) in West Sumatra, Indonesia. - Far Eastern Entomologist 182: 1-9.

[8] Durden, A.L. (2010): Lepidoptera Endemism in Sulawesi (Celebes), Indonesia. - Journal Southern Lepidoptersts News 32(2): 62-70.

[9] Goulet, H., Huber, J.T. (1993): Hymenoptera of The World: An Identification Guide to Families. - Research Branch Agriculture Canada Publication, Canada.

[10] Helmiyetti, Praja, R.D.M., Manaf, S. (2012): Siklus Hidup Jenis Kupu-kupu Papilionidae yang Dipelihara pada Tanaman Jeruk Purut (Citrus hystrix). - Konservasi Hayati 8(2): 41-45.

[11] Huang, D.W., Noyes, J.S. (1994): Parasitoids of the Immature Stages of Economically Important Insect Species (Mainly Hemiptera and Lepidoptera). - Entomology 63: 1-136. 
[12] Kartsev, V.M. (2014): Phenoptosis in Arthropods and Immortality of Social Insect. Biochemistry (Moscow) 79(10): 1032-1048.

[13] Kuroyanagi, T., Yoshikoshi, H., Kinoshita, T., Kawashima, H. (2013): Use Air Circulation to Reduce Wet Leaves under High Humidity Conditions. - Environmental Control in Biology 51(4): 215-220.

[14] Matsuka, S. (2001): Natural History of Birdwing Butterflies.- Matsuka Printing Co, Tokyo.

[15] Nauman, I.D. (1991): Hymenoptera. - Melbourne University Press, Melbourne.

[16] Scriber, J.M., Slansky, F. (1981): The Nutritional Ecology of Immature Insect. - Annual Review of Entomology 26: 183-211.

[17] Solomon, M.E. (1976): Population Dynamics. Second Edition. - Hodder, London.

[18] Straatman, R. (1971): The Life History of Ornithoptera alexandrae Rothschild. - Journal of The Lepidopterists Society 5: 58-64.

[19] Tip-pyang, S., Payakarintarungkul, K., Sichaem, J., Phuwapraisirisan, P. (2011): Chemical Constituents from The Roots of Uvaria rufa. - Chemistry of Natural Compounds 47(3): 944-972.

[20] Vane-Wright, D., De Jong, R. (2003): The Butterflies of Sulawesi Annotated Checklist for a Critical Island Fauna. - Zoologische Verhandelingen: 1-256.

[21] Whitten, T., Henderson, G.S., Mustafa, M. (2002): The Ecology of Indonesia Series Volume IV: The Ecology of Sulawesi. - Periplus Ltd, Singapore. 